M. Novozhylova, V. Kramarenko, O. Chub

\title{
MODELING OF INFORMATION TECHNOLOGY OF MATERIAL RESOURCES MANAGEMENT OF A CONSTRUCTION COMPANY
}

\begin{abstract}
The article's research subject is the information technology of construction company's material resources management. The work's purpose is to construct and implement tools for modeling construction company's material resources management information technology. The article solves the following tasks: determining the place of information technology of construction company's material resources management in the modern construction company's information ecosystem, defining the main components, and building a functional model of construction company's material resources management information technology, taking into account the shortcomings of existing models, creation of the multicriteria optimization model of the considered information technology. The following methods are used: system analysis, structural analysis, mathematical modeling of complex systems and processes, multicriteria optimization. The following results were obtained: a structural analysis of the existing information ecosystem at the regional level construction company, the composition of which is agreed on the organizational structure elements of the enterprise and the stages of the construction life cycle; considered the functions of construction company's material resources management which are realized at various stages of a construction project life cycle; constructed the set-theoretical model of material resources management information technology; determined the functional characteristics of the considered information technology, offered the criteria of information technology efficiency according to the ITIL strategy; constructed the conceptual model of information technology of material resources management. Conclusions: for the first time, developed tools for modeling construction company's material resources management information technology, including a theoretical-multiple model of material resources management information technology; Offered the information technology's conceptual scheme which realizes specific information technology's functional characteristics. The built modeling strategy will provide an opportunity for further development and software implementation of the information technology.
\end{abstract}

Keywords: information flows; construction enterprise; functional model; efficiency criteria.

\section{Introduction (Statement of the problem)}

In the modern world, information becomes an asset that significantly affects the efficiency of doing business in a competitive environment. This is especially true for companies and enterprises that define customer-oriented as a business philosophy and to which construction enterprises belong. Any large company has a significant amount of information that needs to be processed to understand the current state of the company and make a management decision. In the construction company, information processing is complicated by the duration of construction and the presence of a number of construction projects that are carried out simultaneously and are at different stages of their life cycle.

The transformation of construction enterprises into digital companies is actively supported by the state in the context of the course on computerization of all spheres of public life and the transition to online formats.

In 2021, the procedure for maintaining a Unified State Electronic System in the field of construction was updated [1]. The Cabinet of Ministers of Ukraine approved the Concept of Implementation of Construction Information Modeling Technologies (VIM-Technologies) in Ukraine developed by the Ministry of Community Development and Territory of Ukraine, as well as the action plan for its implementation [2]. Thus, the base for the introduction of general information reporting in electronic formats is prepared.

These and other elements of the general information ecosystem of the construction enterprise as new forms of the organization of production are factors of innovative development of the company.

An important and currently little-studied subject area in the general problem of digitalization of construction companies is the construction and optimization of information technology for automated management of various material resources throughout the product life cycle of the construction project.

\section{Analysis of recent research and publications}

An overview of scientific publications in the field of information management is given in [3]. This study summarizes the evolution of knowledge about organizational processes, technologies and tools for creating, integrating, disseminating access organization storage and information security in automated systems. Analysis of the potential application of automation tools at different stages of the construction project was carried out in [4].

In [5] technology is defined as a set of scientific and engineering knowledge embodied in the methods and means of labor, sets of material factors of production, types of their combination to create a particular product or service.

Using the approach [6], information technology at the organizational level is defined as the resources needed to collect, process, store and disseminate information.

The general state and prospects of information technology implementation, as well as the main obstacles to their implementation are considered in [7]. In general, in the information technology market, there are many enterprise management systems that provide increased speed in the information processing process, improve the quality of information for management and help in project planning.

The structure of information technology for controlling the cost of resources, which takes into account the imperfection of information in the description of 
objects and processes of the subject area, was defined in [8].

Functional-modular approach to building a conceptual model of information technology as such, proposed in [9]. The main tasks of information analysis are considered, in particular the tasks of evaluating results, clustering activities by areas and forecasting development prospects on the example of scientific activity.

The technique of object-oriented analysis for modeling information on design and construction is implemented in [10]. This approach is used to model information in terms of the fundamental ideas that underlie object-oriented technology, ie types and classes of objects, methods, queries, encapsulation and inheritance.

The general principles of building an artificial intelligence system project for a company's business processes using the so-called "business-artificial intelligence" alignment model are considered in [11]. The importance of a common understanding of the project between all members of the project team, both from business departments and from the IT department, is emphasized.

The development of the architectural field of construction is BIM-technology (Building Information Model) is a new approach to digital information management in the construction industry, which allows you to virtually reproduce the object, increase safety and reliability of buildings and structures, control the quality and speed of construction, significantly reduce probability of errors in projects, reduce construction costs and optimize costs during operation. [12] proposes an approach to using BIM as a tool of lean technology, which allows you to make the right decisions at different stages of construction. Therefore, integration with BIM is necessary for modern information technology in the field of construction.

Despite the benefits of BIM, data compatibility is a barrier to its adoption. To solve this problem, [13] presents the BIM Interoperability Adoption Model (BIAM) as a link between organizational, semantic, legal and technical factors to determine compatibility issues in the early stages of BIM implementation.

The development of management technologies in the construction industry is a matrix information technology for linking 1C software and Microsoft Project into a single information processing system for managing construction companies and projects - NadProject [14]. This technology is designed to assist the construction project manager in developing plans, allocating resources, tracking progress and analyzing workloads, and integrating this information with the enterprise information system. Despite the benefits of BIM, data compatibility is a barrier to its adoption. To solve this problem, [13] presents the BIM Interoperability Adoption Model (BIAM) as a link between organizational, semantic, legal and technical factors to determine compatibility issues in the early stages of BIM implementation.
The development of management technologies in the construction industry is a matrix information technology for linking $1 \mathrm{C}$ software and Microsoft Project into a single information processing system for managing construction companies and projects - NadProject [14]. This technology is designed to assist the construction project manager in developing plans, allocating resources, tracking progress and analyzing workloads, and integrating this information with the enterprise information system.

\section{Selection of previously unsolved parts of the overall problem. The purpose of the work}

Despite the constant development of models, methods and information systems for resource management, in particular in the construction industry, the existing systems lack the functionality to collect, store and process information about changes in the external environment of construction projects [15].

There is also no possibility to support decisionmaking in conditions of uncertainty, which in turn negatively affects the effectiveness of operational resource management and profitability of projects.

Moreover, in order to make more sound management decisions in the field of resource management in construction, the relevant processes, tools and methods of material resource management of construction projects should be allocated as a separate field of knowledge, as proposed in [16].

Another unresolved problem is to take into account the wide territorial distribution of construction sites, along with the need to obtain relevant information in different locations and in a single control center, ie the creation of principles of cloud technology as a basis for information technology management of construction resources.

This issue is especially relevant for solving the problem of automation of information flow management of a large construction company at the regional level. The main technical and economic characteristics of such an enterprise are as follows: simultaneous implementation of \pm 10 projects at different stages of the life cycle, 10002000 employees, builds simultaneously in different areas of the city and is engaged in different types of construction. These are such companies as Zhitlobud-2 (https://zhilstroj-2.ua), Zhitlobud-1 (https://gs1.com.ua/), Avantazh: (https://avantazh.ua/), Stroy- City (https://stroycity.com.ua/uk).

The purpose of the work - the construction and implementation of tools for modeling information technology management of material resources of the construction company under the conditions of using existing approaches to company resource management and software architecture.

\section{Materials and Methods}

All divisions and zones of activity of the construction enterprise according to its organizational structure are subject to automation (fig. 1). 


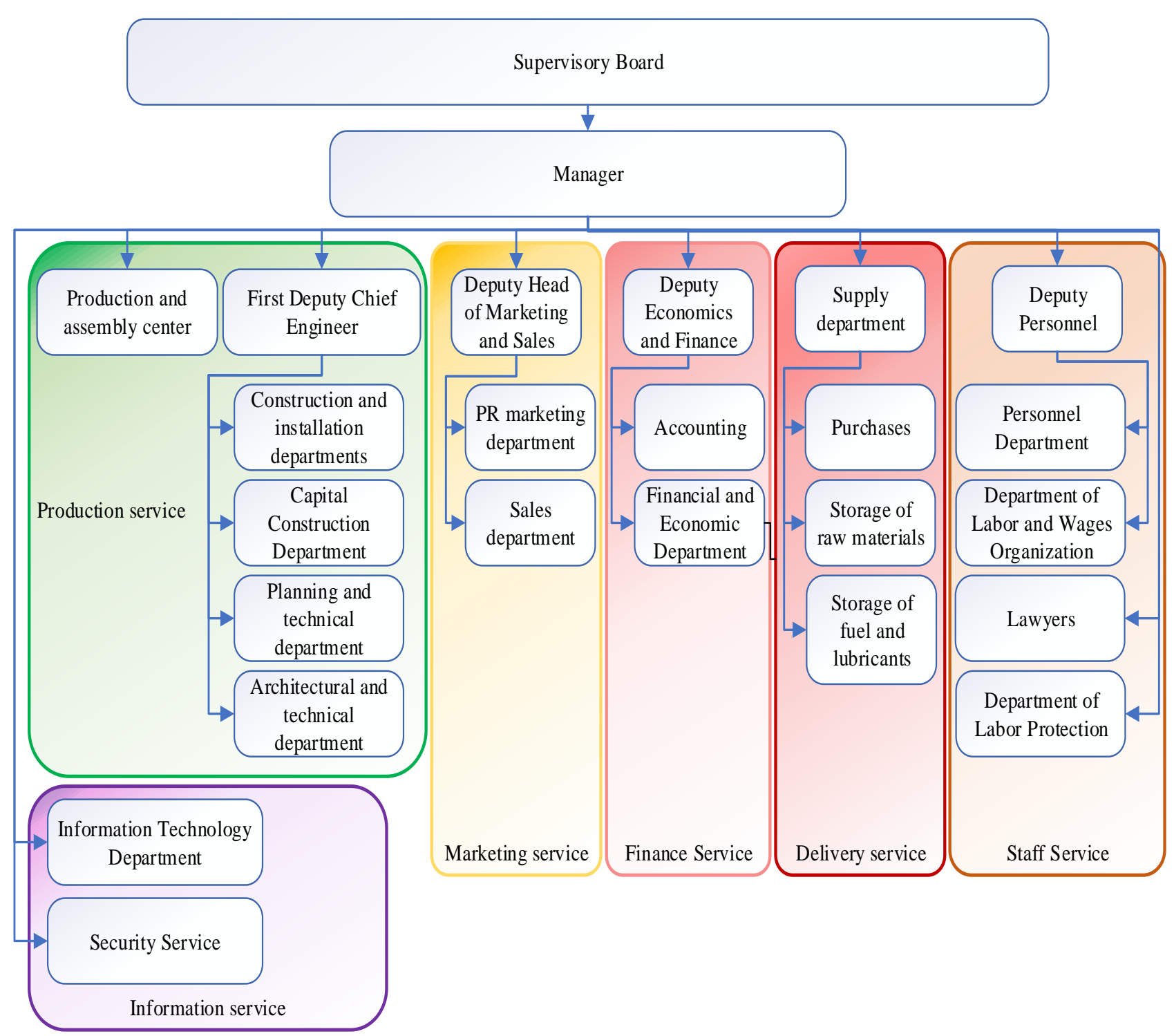

Fig. 1. Organizational structure of a typical construction enterprise

The analysis of the current state of the process of information ecosystem formation at the construction enterprise of a certain - regional - level showed that today each service of the enterprise uses many software applications of different architecture and orientation according to the subject area of operation.

In the subject area of the production service, the use of BIM-server of BIMcloud [17] allows simultaneous processing of the project by a team of designers, which allows you to see a holistic picture of the project and avoid conflicts when designing compatible components of ventilation and electricity. The team work can be attended by a construction worker as a direct contractor who receives current design data in real time.

Estimation by the finance service is carried out with the help of the product Construction Technologies: Estimate 8 (https://smeta.ua/). The wage module in $1 \mathrm{C}$ calculates the wages that must be paid based on the work performed by the employee or the number of changes worked. Thanks to the placement of the $1 \mathrm{C}$ system in the cloud, employees of the enterprise according to the level of access, can view or edit current accounting data, control the balance of resources and place orders with other departments.

The M.E.DOC program (https://medoc.ua/) is used to submit official reports to the controlling bodies in electronic form. To control, analyze and simplify the sale of apartments, the marketing service uses the CRM system AMO-CRM (https://www.amocrm.com.ua/).

The personnel service and security service have an automatic face recognition system CaMaP from Kobi software [18], which stores in the database information about each person who passed to the object and the access control system (ACS). These systems generate reports on the time a person is at the facility. The video surveillance system covers the entire territory of the construction site at the same time. The function of recording on electronic media is implemented.

The supply service also uses the $1 \mathrm{C}$ information system. Automated scales are installed at the exit from the territory of the production and assembly center, the system records the date, time and weight of each machine when passing through them, this data is stored on the server. If it is a company car, the driver has a consignment note with a 
QR code, he scans it and the system adds to the electronic consignment note in $1 \mathrm{C}$ indicators from the scales and saves a photo of the car from the camera at the entrance. The system of sensors on concrete units exports the actual data on the amount of materials used for the manufacture of concrete, and stores in the system $1 \mathrm{C}$. The $1 \mathrm{C}$ system of the enterprise saves production reports for change and calculates the prime cost of the made products. Users record the movement of materials and therefore see the real balances in warehouses.

With the help of the transport control system from Moniterra (http://moniterra.com.ua/) the dispatcher controls the real location of the transport, in addition, the functions of automatic collection and transmission of data on the distance traveled and the amount of fuel consumed in the $1 \mathrm{C}$ system are implemented.
Zhytlobud-2's immediate plans include the integration of BIM360 [19] and Navisworks [20] architectural technologies for Revit, which make it possible to simulate the planned appearance of the building in accordance with the materials used. Therefore, one of the important tasks in the design, development and implementation of information technology must take into account the level of the information structure created at the enterprise.

In general, the use of information technology in a typical construction company can be submitted at the stages of the life cycle of housing construction: preinvestment, pre-project, design, construction, operation. On the other hand, these information technologies can also be arranged according to the subject areas of design, which are represented by the relevant services of the enterprise (fig. 2).

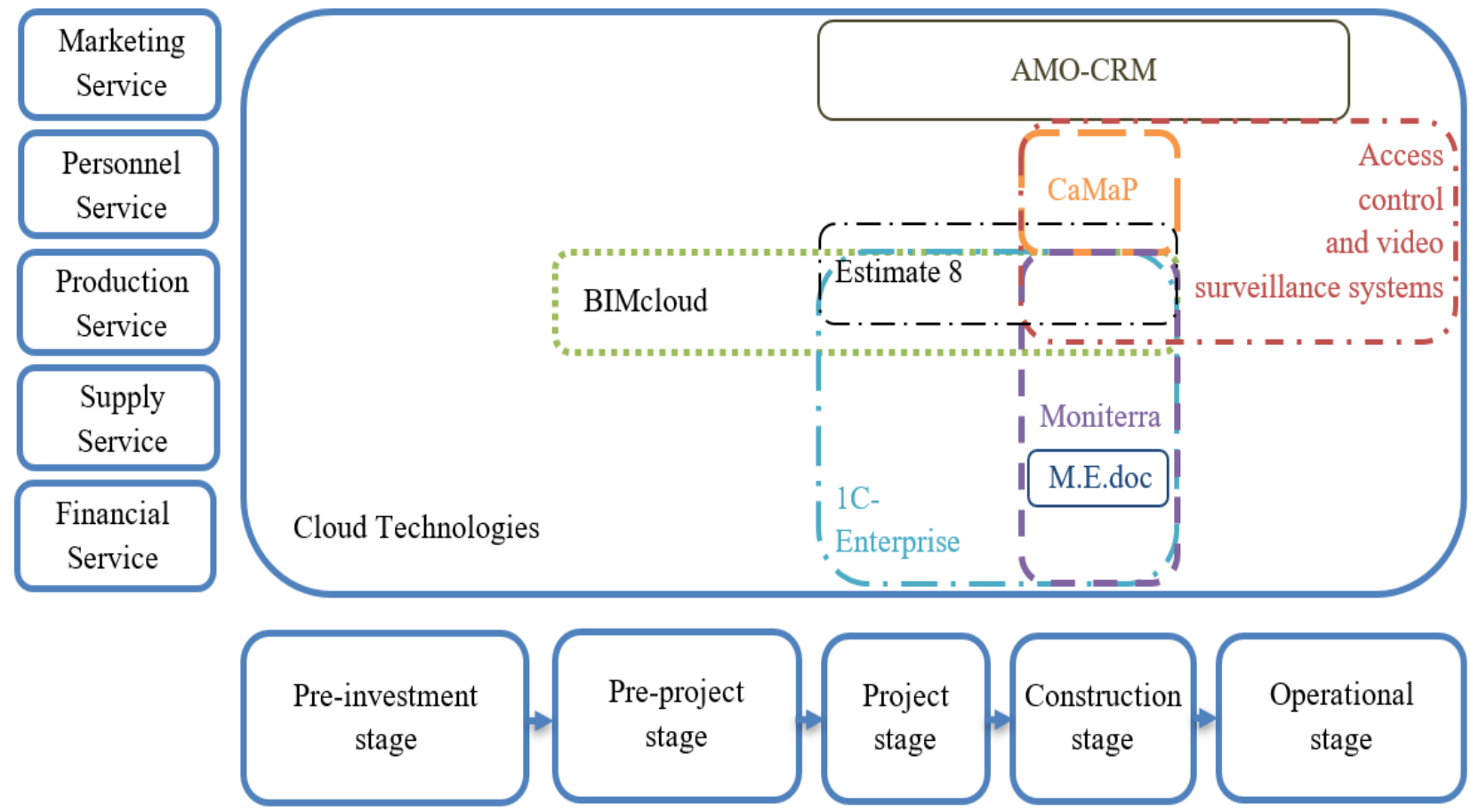

Fig. 2. The use of information technologies according to the life cycle stage of construction and the subject area of application

Obviously, information technology and systems are part of the resource potential of the enterprise. In general, the resource potential of the enterprise is a set of its tangible, labor, intangible, financial, time, information resources, including the ability of employees to effectively use these resources to perform the intended technological process and achieve strategic and current goals of the enterprise [21].

We distinguish among the set of resources material resources (inventories, current assets) that participate in the process of economic activity during one production cycle, while completely changing their form and transfer their value to the costs of the enterprise.

Pre-investment, pre-project and project stages of the life cycle of a construction project are such that they practically do not require the use of material resources. However, at these stages, all the necessary information for the construction phase is formed, namely - the project, which generates the composition, structure, quantity, time of receipt and other characteristics of the set of material resources.

The functions of material resource management can be reduced to four main groups [21]:

1. Planning the parameters of material flows, ie planning the need for material resources in conjunction with the choice of suppliers, forms and channels of supply of resources.

2. Organization of the process of receipt of material resources.

3. Regulation of the parameters of material flows by bringing them closer to the actual needs of the enterprise.

4. Periodic control of the process of resource use based on monitoring the parameters of construction works.

The functions of material resources management are implemented at different stages of the life cycle of the construction project (fig. 3). 


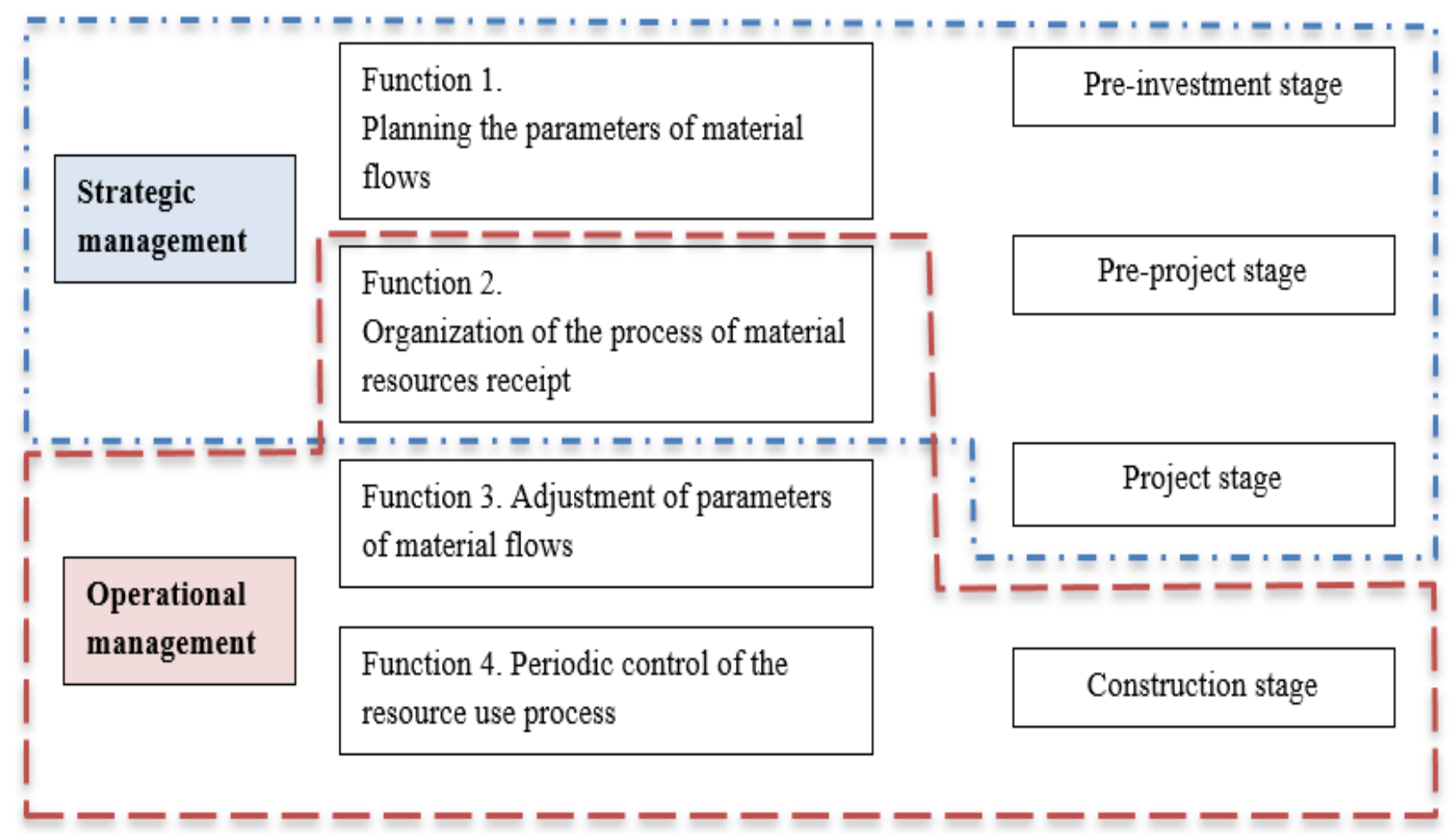

Fig. 3. The ratio of stages of the life cycle of the construction project, levels and functions of material resources management

These management functions are the main tasks of information technology of material resources management (ITmmr $)$ of the construction enterprise.

By definition, information technology as a finite ordered set of methods and means of information processing (Information Processing) - elements of information technology - can be formalized as follows:

$$
I T m m r=<\left\{I P_{1}, \ldots, I P_{N}\right\} \times\left\{R_{1}, \ldots, R_{M}\right\}>,
$$

where $I P_{1}, \ldots, I P_{N}, R_{1}, \ldots, R_{M}-$ sets of elements of information technology and means of their ordering, respectively, $\mathrm{N}$ and $\mathrm{M}$ - power of sets IP and R.

As a resource, information technology ITmmr must have certain characteristics of $\mathrm{P}$ (functional and cost), and must meet certain information needs of information technology consumers.

The following functional characteristics $P_{1}, \ldots, P_{6}$ of information technology of material resources management are generalized:

$P_{1}-$ use of computing paradigm of cloud technologies;

$P_{2}-$ availability of a unified base of material resources;

$P_{3}$ - compliance with the regulatory framework for informatization of the economic activity of the enterprise;

$P_{4}$ - availability of mechanisms to support strategic and operational management decisions;

$P_{5}$ - support for data exchange (import and export) with external sources;
$P_{6}$ - availability of means of integration into the existing information ecosystem of the enterprise;

$P_{7}$ - modular structure of information technology.

Each of the selected characteristics is vector (multifactor), the content of which is revealed in the subsequent stages of modeling.

Development and implementation of information technology for material resources management requires qualified personnel, financial and time costs. Therefore, when creating information technology, it is necessary to determine the metrics of its effectiveness. To date, an arsenal of approaches to determining the effectiveness of information technology, both economic and systemic. The difficulty lies in the fact that the quantitative assessment of the actual economic efficiency of investment in the creation and implementation of information technology as such does not cover all the results and consequences of development.

A set of elements $I P_{1}, \ldots, I P_{N}$ of the information technology and the main flows of information exchange $R_{1}, \ldots, R_{M}$ we present in the form of a conceptual model (fig. 4), which has a clearly defined modular structure (property).

It is assumed that the data processing modules should be placed in the cloud (property). The arrows in the diagram indicate the information flows between the technology modules.

Analysis of the available means of determining the effectiveness of information technology in terms of subject area showed that the most acceptable is the service strategy ITIL (IT Infrastructure Library) [22], which implements a systematic approach to determining the effectiveness of information technology. 


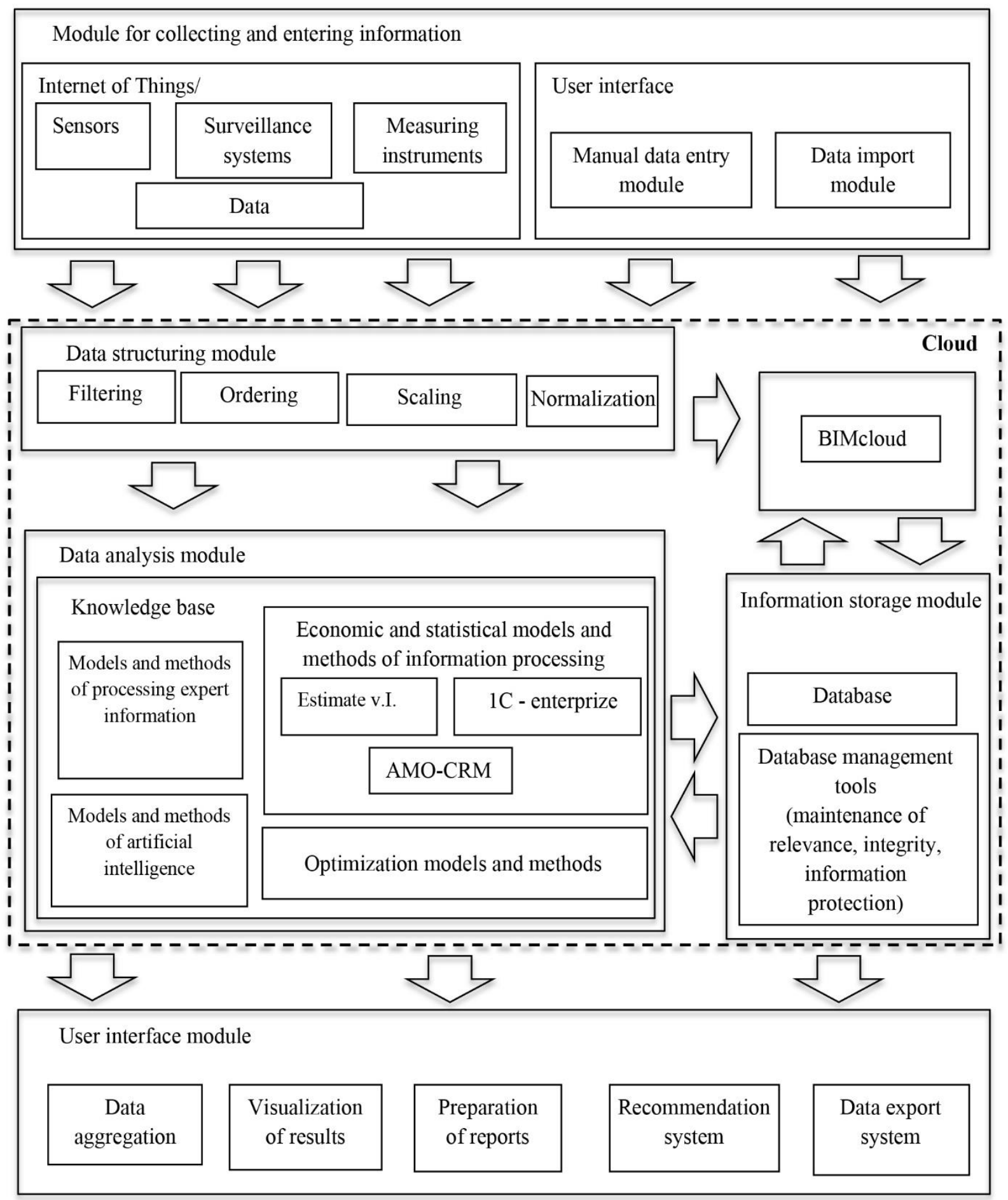

Fig. 4. Conceptual model of information technology of resource management

According to the ITIL strategy, the functional efficiency $K_{F}(I P)$ of information technology management of material resources of a construction company is assessed by the results of operational $\left\{K_{F 1}(I P)\right\}$, financial $\left\{K_{F 2}(I P)\right\}$, strategic $\left\{K_{F 3}(I P)\right\}$, industrial $\left\{K_{F 4}(I P)\right\}$ industries. In turn, the criterion of operational efficiency $K_{F 1}(I P)$ for ITmmr includes such criteria as: reducing information processing time $K_{F 11}(I P)$ and resource delivery time $K_{F 12}(I P)$, increasing the productivity of the supply service $K_{F 13}(I P)$, increasing the reliability of the supply process $K_{F 14}(I P)$ to reduce risks $K_{F 15}(I P)$ (by type of resources), improving the use of resources with limited life of $K_{F 16}(I P)$.

The criterion of efficiency $K_{F 2}(I P)$ of financial activity concerning ITmmr includes such partial criteria, as reduction of direct expenses $K_{F 21}(I P)$ for creation of a product of the construction project, criterion of growth of 
margin $K_{F 22}(I P)$, criterion of execution of the budget of the construction project $K_{F 23}(I P)$.

The criterion of strategic efficiency $K_{F 3}(I P)$ includes the criteria of strengthening the market position of the enterprise $K_{F 31}(I P)$, determining the competitive types of housing projects $K_{F 32}(I P)$, improving the quality of construction $K_{F 33}(I P)$, offering new types of services in the field of housing $K_{F 34}(I P)$, improving the comfort of the construction project product $K_{F 34}(I P)$.

The criterion of industrial efficiency $K_{F 4}(I P)$ contains such partial criteria as the criterion of growth of the company's share in the housing market $K_{F 41}(I P)$, the criterion of compliance with construction standards and regulations $K_{F 42}(I P)$, the criterion of recognition of the enterprise as a leader in the housing market $K_{F 43}(I P)$.

Thus:

$$
K_{F}(I P)=F\left[\lambda_{i}, K_{F i}(I P)\right], i=1, \ldots 4,
$$

where $\mathrm{F}$ is a certain type of hierarchical convolution of partial efficiency criteria $K_{F i}(I P), \lambda_{i} \quad-$ isomorphism parameters that lead heterogeneous partial efficiency criteria to a single metric,

$$
\lambda_{i}=\left\{\lambda_{i j}\right\}, j=1,2, \ldots J_{i},
$$

where $J_{i}, i=1, \ldots, 4$ is the number of partial criteria by types of information technology efficiency.

\section{Research results and their discussion}

A structural analysis of the existing information ecosystem at a construction company at the regional level in conjunction with the elements of the organizational structure of the enterprise and the stages of the construction life cycle. The existing elements of automated information processing are considered as reference points for the development of information technology management of material resources of the enterprise.

The functions of management of material resources of the construction enterprise which are realized at various stages of a life cycle of the construction project are generalized. These functions become the main tasks of information technology of material resources management. Based on the constructed set-theoretic model of information technology, its functional characteristics are determined.

Mechanisms for implementing the functional characteristics of information technology are provided in the conceptual model of information technology management of material resources. More detailed: the property $P_{2}$ is the presence of a unified database of material resources and is provided by the data structuring module and the information storage module. Data analysis modules and user interface elements act as mechanisms to support strategic and operational management decisions. Implementation of the property $P_{5}$ is the support of data exchange (import and export) with external sources provided in the module of collection and input of information and elements of the user interface. Property $P_{3}$ is a compliance with the regulatory framework for informatization of economic activity of the enterprise is provided by the inclusion of appropriate additional modules, and finally property $P_{6}$ is the availability of means of integration into the existing information ecosystem of the enterprise - is provided by defining the place of existing information. technology implementation. Criteria for the effectiveness of information technology according to the ITIL strategy, which provide for quantitative interpretation.

\section{Conclusions and prospects for further development}

The developed means of modeling of information technology of management of material resources of the building enterprise include the theoretical-multiple model of information technology of management of material resources; the functional characteristics of the considered information technology are determined. The developed modeling strategy will provide an opportunity for further development and software implementation of information technology.

\section{References}

1. Resolution of the Cabinet of Ministers of Ukraine of June 23, 2021 № 681 "Some issues of ensuring the functioning Unified State Electronic System in the construction field" [Postanova Kabinetu Ministriv Ukrainy vid 23 chervnia 2021 r. № 681 "Deiaki pytannia zabezpechennia funktsionuvannia Yedynoi derzhavnoi elektronnoi systemy u sferi budivnytstva"], available at : https://zakon.rada.gov.ua/laws/show/681-2021-\%D0\%BF\#Text (last accessed 16.08.2021).

2. Order of the Cabinet of Ministers of Ukraine "On approval of the Concept of implementation of building information modeling technologies (BIM-technologies) in Ukraine and approval of the action plan for its implementation" [Rozporiadzhennia Kabinetu Ministriv Ukrainy "Pro skhvalennia Kontseptsii vprovadzhennia tekhnolohii budivelnoho informatsiinoho modeliuvannia (VIMtekhnolohii) v Ukraini ta zatverdzhennia planu zakhodiv z yii realizatsii"], available at : https://zakon.rada.gov.ua/laws/show/1522021-\%D1\%80\#Text (last accessed 16.08.2021).

3. Sharma, A., Rana, N. P., Nunkoo, R. (2021), "Fifty years of information management research: A conceptual structure analysis using structural topic modeling", International Journal of Information Management, Vol. 58, 102316. DOI: https://doi.org/10.1016/j.ijinfomgt.2021.102316

4. Chen, Q., de Soto, G. B., Adey, B. T. (2018), "Construction automation: Research areas, industry concerns and suggestions for advancement", Automation in Construction, Vol. 94, P. 22-38. DOI: https://doi.org/10.1016/j.autcon.2018.05.028 
5. Tomashevsky, O. M., Tsegelyk, G. G., Viter, M. B., Duduk, V. I. (2012), Information technologies and business process modeling [Informatsiini tekhnolohii ta modeliuvannia biznes-protsesiv], Kyiv, $296 \mathrm{p}$.

6. "Governance of IT for the organization: ISO/IEC 38500:2015", available at : https://www.iso.org/obp/ui/\#iso:std:isoiec:38500:ed-2:v1:en (last accessed 16.08.2021).

7. Kraychuk, S. O. (2016), "The state of introduction of information technologies in management of modern enterprises" ["Stan zaprovadzhennia informatsiinykh tekhnolohii v upravlinni suchasnymy pidpryiemstvamy"], Efficient economy, No. 4.

8. Zolotukhina, O. A. (2018) "The structure of information technology control of resource costs" ["Struktura informatsiinoi tekhnolohii kontroliu vytrat resursiv"], Telecommunication and information technologies, No. 1 (58), P. 96-104.

9. Biloshchytsky, A. A., Biloshchytska, S. V., Lisnevsky, R. V., Lyashchenko, T. O. (2011), "Improvement of methods and means of modern information technologies in teaching and control of knowledge" ["Udoskonalennia metodiv i zasobiv suchasnykh informatsiinykh tekhnolohii v navchanni i kontroli znan"], Management of complex systems development, Vol. 5, P. 87-94.

10. Alshawi, M., Underwood, J. (1996), "Applying object-oriented analysis to the integration of design and construction", Automation in Construction Volume, No. 5 (2), P. 105-121. DOI: https://doi.org/10.1016/0926-5805(95) 00023-2.

11. Takeuchi, H., Yamamoto, S. (2020), "Business Analysis Method for Constructing Business-AI Alignment Model", Procedia Computer Science, Vol. 176, P. 1312-1321. DOI: https://doi.org/10.1016/j.procs.2020.09.140

12. Eldeep, Ah. M., Moataz, A. M., Farag, L. M., El-hafez, A. (2021), "Using BIM as a lean management tool in construction processes - A case study", Ain Shams Engineering Journal, In Press, Corrected Proof. DOI: https://doi.org/10.1016/j.asej.2021.07.009

13. Shehzad, M. H. F., Ibrahim, R. B., Yusof, A. F., Khaidzir, Kh. A. M., Igbal, M., Razzaq, S. (2021), "The role of interoperability dimensions in building information modelling", Computers in Industry, Vol. 129, 103444. DOI: https://doi.org/10.1016/j.compind.2021.103444

14. Tesla, Yu. M., Oberemok, N. V, Latysheva, T. V. (2015), "Matrix information technology NADPROJECT project management of construction companies" ["Matrychna informatsiina tekhnolohiia NADPROJECT upravlinnia proektamy budivelnykh kompanii"], Management of complex systems development, No. 22, P. 84-88.

15. Kramarenko, V. I., Novozhilova, M. V. (2020), "Analysis of information systems for managing material resources of a construction company" ["Analiz informatsiinykh system upravlinnia materialnymy resursamy budivelnoho pidpryiemstva"], Prospects for the development of territories: theory and practice, P. 468-470.

16. Danshina, S. Yu. (2021), "Generalized approach to the management of material resources of the project", Innovative Technologies and Scientific Solutions for Industries, No. 1 (15), P. 43-51. DOI: https://doi.org/10.30837/ITSSI.2021.15.043

17. "Graphisoft BIMcloud", available at : https://graphisoft.com/ru/solutions/bimcloud/ (last accessed 16.08.2021).

18. "Intelligent software Samar" ["Intelektualne prohramne zabezpechennia Samar"], available at : https://kobi.ua/product/intellektualnoe-programmnoe-obespechenie-camap/ (last accessed 16.08.2021).

19. "BIM 360", available at : https://bim360.csd.ru/bim360build/ (last accessed 16.08.2021).

20. "Navisworks", available at : https://www.autodesk.com/products/navisworks/overview (last accessed 16.08.2021).

21. Chub, O. I., Novozhilova, M. V. (2017), Multicriteria optimization of resource provision of renewable works on infrastructure objects [Bahatokryterialna optymizatsiia resursnoho zabezpechennia vidnovliuvanykh robit na infrastrukturnykh obiektakh] : Monograph, Kharkiv, $150 \mathrm{p}$.

22. Axelos. ITIL Foundation, ITIL 4 edition. 1. UK : TSO (The Stationery Office). 2019. 222 p.

Received 23.08.2021

\section{Відомості про авторів / Сведения об авторах / About the Authors}

Новожилова Марина Володимирівна - доктор фізико-математичних наук, професор, Харківський національний університет міського господарства імені О. М. Бекетова, завідувач кафедри, Харків, Україна; email: marina.novozhilova@kname.edu.ua; ORCID: http://orcid.org/0000-0002-9977-7375.

Новожилова Марина Владимировна - доктор физико-математических наук, профессор, Харьковский национальный университет городского хозяйства имени А. Н. Бекетова, заведующая кафедрой, Харьков, Украина.

Novozhylova Maryna - Doctor of Sciences (Physical and Mathematical), Professor, O. M. Beketov National University of Urban Economy in Kharkiv, Head of the Department, Kharkiv, Ukraine.

Крамаренко Владислав Ігорович - Харківський національний університет міського господарства імені O. М. Бекетова, аспірант, Харків, Україна; email: Vladyslav.Kramarenko@kname.edu.ua; ORCID: https://orcid.org/0000-00024065-9972.

Крамаренко Владислав Игоревич - Харьковский национальный университет городского хозяйства имени А. Н. Бекетова, аспирант, Харьков, Украина. Ukraine.

Kramarenko Vladyslav - O. M. Beketov National University of Urban Economy in Kharkiv, Postgraduate Student, Kharkiv,

Чуб Ольга Ігорівна - кандидат економічних наук, Харківський національний університет імені В. Н. Каразіна, доцент кафедри теоретичної та прикладної системотехніки, Харків, Україна; email: O.I.Chub@karazin.ua; ORCID: https://orcid.org/0000-0002-1216-856X.

Чуб Ольга Игоревна - кандидат экономических наук, Харьковский национальный университет имени В. Н. Каразина, доцент кафедры теоретической и прикладной системотехники, Харьков, Украина.

Chub Olga - PhD (Economics Scienses), V. N. Karazin Kharkiv National University, Assocciate Professor of the Department of Theoretical and Practical Systemotechnics, Kharkiv, Ukraine. 


\title{
МОДЕЛЮВАННЯ ІНФОРМАЦЙНОЇ ТЕХНОЛОГІЇ УПРАВЛІННЯ МАТЕРІАЛЬНИМИ РЕСУРСАМИ БУДІВЕЛЬНОГО ПІДПРИЕМСТВА
}

\begin{abstract}
Предметом дослідження в статті $\epsilon$ інформаційна технологія управління матеріальними ресурсами будівельного підприємства. Мета роботи - побудова та реалізація інструментальних засобів моделювання інформаційної технології управління матеріальними ресурсами будівельного підприємства. В статті вирішуються наступні завдання: визначення місця інформаційної технології управління матеріальними ресурсами будівельного підприємства в інформаційній екосистемі сучасного будівельного підприємства, визначення основних складових та побудова функціональної моделі інформаційної технології управління матеріальними ресурсами будівельного підприємства, що враховує недоліки існуючих моделей, визначення частинних показників ефективності інформаційної технології та створення оптимізаційної багатокритеріальної моделі інформаційної технології, що розглядається. Використовуються такі методи: системного аналізу, структурного аналізу, математичного моделювання складних систем та процесів, багатокритеріальної оптимізації. Отримано наступні результати: проведено структурний аналіз наявної інформаційної екосистеми на будівельному підприємстві регіонального рівня, склад якої узгоджено за елементами організаційної структури підприємства та етапів життєвого циклу будівництва; розглянуто функції управління матеріальними ресурсами будівельного підприємства, що реалізуються на різних етапах життєвого циклу будівельного проєкту; побудовано теоретико-множинну модель інформаційної технології управління матеріальними ресурсами; визначено функціональні характеристики інформаційної технології, що розглядається, запропоновано критерії ефективності інформаційної технології за стратегією ITIL; побудовано концептуальну модель інформаційної технології управління матеріальними ресурсами. Висновки: вперше розроблено засоби моделювання інформаційної технології управління матеріальними ресурсами будівельного підприємства, що включають теоретикомножинну модель інформаційної технології управління матеріальними ресурсами; запропоновано концептуальну схему інформаційної технології, що реалізує визначені функціональні характеристики інформаційної технології. Побудована стратегія моделювання забезпечить можливість подальшого розвитку та програмної реалізації інформаційної технології.
\end{abstract}

Ключові слова: інформаційні потоки; будівельне підприємство; функціональна модель; критерії ефективності.

\section{МОДЕЛИРОВАНИЕ ИНФОРМАЦИОННЫХ ТЕХНОЛОГИЙ УПРАВЛЕНИЯ МАТЕРИАЛЬНЫМИ РЕСУРСАМИ СТРОИТЕЛЬНОГО ПРЕДПРИЯТИЯ}

\begin{abstract}
Предметом исследования в статье является информационная технология управления материальными ресурсами строительного предприятия. Цель работы - построение и реализация инструментальных средств моделирования информационной технологии управления материальными ресурсами строительного предприятия. В статье решаются следующие задачи: определение места информационной технологии управления материальными ресурсами строительного предприятия в информационной экосистеме современного строительного предприятия, определение основных составляющих и построение функциональной модели информационной технологии управления материальными ресурсами строительного предприятия, учитывающий недостатки существующих моделей, определение частных показателей эффективности информационной технологии и создание оптимизационной многокритериальной модели информационной технологии, рассматривается. Используются следующие методы: системного анализа, структурного анализа, математического моделирования сложных систем и процессов, многокритериальной оптимизации. Получены следующие результаты: проведено структурный анализ имеющейся информационной экосистемы на строительном предприятии регионального уровня, состав которой согласован с элементами организационной структуры предприятия и этапов жизненного цикла строительства; рассмотрены функции управления материальными ресурсами строительного предприятия, реализуемых на различных этапах жизненного цикла строительного проекту; построено теоретико-множественную модель информационной технологии управления материальными ресурсами; определены функциональные характеристики информационной технологии, рассматривается, предложены критерии эффективности информационной технологии по стратегии ITIL; построено концептуальную модель информационной технологии управления материальными ресурсами. Выводы: впервые разработаны средства моделирования информационной технологии управления материальными ресурсами строительного предприятия, включающие теоретико-множественную модель информационной технологии управления материальными ресурсами; предложена концептуальная схема информационной технологии, реализует определенные функциональные характеристики информационной технологии. Построена стратегия моделирования обеспечит возможность дальнейшего развития и программной реализации информационной технологии.
\end{abstract}

Ключевые слова: информационные потоки; строительное предприятие; функциональная модель; критерии эффективности.

\section{Бібліографічні описи / Bibliographic descriptions}

Новожилова М. В., Крамаренко В. І., Чуб О. І. Моделювання інформаційної технології управління матеріальними ресурсами будівельного підприємства. Сучасний стан наукових досліджень та технологій в промисловості. 2021. № 3 (17). C. 32-40. DOI: https://doi.org/10.30837/ITSSI.2021.17.032

Novozhylova, M., Kramarenko, V., Chub, O. (2021), "Modeling of information technology of material resources management of a construction company", Innovative Technologies and Scientific Solutions for Industries, No. 3 (17), P.32-40. DOI: https://doi.org/10.30837/ITSSI.2021.17.032 